\title{
CITY OF PORTLAND CONVERSION TO CUT-OFF FIXTURES
}

\author{
WILLIAM A. HUGHES
}

Operations Supervisor, Street Lighting, City of Portland

1120 S.W. Fifth Avenue, Portland, Oregon 97204-169 U.S.A.

In 1980, the City of Portland began a conversion project to change out all existing mercury vapor street lights to high pressure sodium. During the planning and design portion of the project, the City hired a consulting firm to look at our existing system and make recommendations as to light source and fixture configuration. After some on site studies of existing street lighting, it was recommended that all arterial streets of the City of Portland be converted from mercury vapor to high pressure cut-off fixtures, in order to cut down glare in the eyes of drivers. Secondly, it was recommended that, on arterial streets, the City could no longer afford to light "key-hole to key-hole." It was important to confine the light to the street right-of-way.

The first year after the conversion was a period of adjustment for citizens adjacent to the arterial streets. The comments were mixed, with those citizens who no longer were getting "security" lighting, to those who had been harassed for years by glare light and light trespass from the street lights, not allowing them to look out on the street or sleep peacefully in their bedrooms. Many amateur astronomers called to compliment the City for removing the glare, allowing them once again to view the heavens.

The City continues to place cut-off fixtures in its system, especially in new subdivisions where views are an esthetic benefit. To prevent disturbing a rural atmosphere, many people are, in fact, requesting that street lights not be installed in their area at all.

The reason for our success with cut-off fixtures is because of our diligence toward educating citizens to the excellent attributes of the non-glare streets. Today, eight years later, you will be hard pressed to find any citizens who would like to see the City go back to the old high glare fixtures. Most people I talk to are very comfortable not having to see through the glare of a non cut-off fixture. My observations also indicate that other cities in the area, as well as the Departments of Transportation in both Oregon and Washington states are beginning to use cut-off fixtures for all new installations.

Non-glaring fixtures are much appreciated. However, education as to their fine attributes is the key to acceptance. 